10. Ushakov, S. A., Lukin, S. Ju., Mitrejkin, Ju. V. (2011). Taktika lechenija perelomov bedrennoj kosti u pacientov s politravmoj. Genij ortopedii, 3, 17-22.

11. Shishhuk, V. D. (2010). Sovershenstvovanie metodov lechenija pri tjazhkih avtodorozhnyh travmah. Visnik Sums'kogo derzhavnogo universitetu. Ser. Medicina, 2, 192-199.

12. Cherkes-Zade, D., Monesi, M., Marcolini, A. (2003). Hirurgicheskoe lechenie perelomov distal'nogo otdela bedren- noj kosti s ispol'zovaniem sistemy LISS. Vestnik travmatologii i ortopedii im. N. N. Priorova, 3, 36-42.

13. Soylemez, M., Ozkan, K., Türkmen, I., Sahin, A., Yildiz, Y., Erturk, S. (2015). A biomechanical comparison of proximal femoral nails and locking proximal anatomic femoral plates in femoral fracture fixation A study on synthetic bones. Indian Journal of Orthopaedics, 49 (3), 347. doi: 10.4103/00195413.156220

Дата надходження рукопису 05.02.2016

Власенко Дмитро В'ячеславович, аспірант, кафедра екстреної та невідкладної медичної допомоги, ортопедії та травматології, Харківський національний медичний університет, пр. Науки, 4, м. Харків, Україна, 61022

E-mail: xupypg@mail.ru

Литовченко Віктор Олексійович, доктор медичних наук, професор, кафедра екстреної та невідкладної медичної допомоги, ортопедії та травматології, Харківський національний медичний університет, пр. Науки, 4, м. Харків, Україна, 61022

Гарячий Свгеній Владиславович, кандидат медичних наук, асистент, кафедра екстреної та невідкладної медичної допомоги, ортопедії та травматології, Харківський національний медичний університет, пр. Науки, 4, м. Харків, Україна, 61022

E-mail: garja4ij@ukr.net

Власенко В'ячеслав Григорович, кандидат медичних наук, доцент, кафедра екстреної та невідкладної медичної допомоги, ортопедії та травматології, Харківський національний медичний університет, пр. Науки, 4, м. Харків, Україна, 61022

UDC 616.006.6-036.22

DOI: $10.15587 / 2313-8416.2016 .64835$

\title{
EPIDEMIOLOGICAL FEATURES OF THE SKIN CANCER
}

\author{
(C) O. Oshyvalova
}

Background. The relevance of the study of oncological pathology of the skin is due to the annual increase of morbidity rate of skin cancer and significantly high mortality rate among patients. The research of epidemiological features of skin cancer will identify risk groups and those who need primary medical care.

The basis for the research of the epidemiological features of skin cancer among the contingent of SIS - State Institution of Science "Research and Practical Centre of Preventive and Clinical Medicine" of the State Administrative Department (SIS “RPC PCM” SAD) is personalized information on patients that's stored in the database of the SIS since 1996. For the retrospective epidemiological analysis were used data from 2005 to 2014. The obtained results were compared with corresponding figures among patients from Kyiv and Ukraine.

Results. The morbidity rate of melanoma and NMCS (Non-melanoma cancers of the skin) is higher than the corresponding figures of the population of Kyiv and Ukraine, despite the decline in the incidence of melanoma in 2014 by $14 \%$ compared to the year 2013. The mortality rate of patients with skin cancer, mainly due to patients with melanoma, among the contingent of SIS is also higher than the corresponding figures of the population of Kyiv and Ukraine. The majority of patients with skin cancer were men of the 2nd period of middle age and elderly age. The highest morbidity rate of skin cancer was registered in age groups of 65-74 years old and 75 years old and older regardless of gender. The recurrence and prolongation of oncological process were registered among patients with melanoma in $2.3 \%$, and among patients with NMCS- $1.1 \%$ annually.

Conclusions. The obtained results showed a significant prevalence of skin cancer among the contingent of SIS compared with the morbidity rate of melanoma among the population of Kyiv and Ukraine. The analysis of epidemiological characteristics show the need for raising awareness of primary care physicians of the earliest clinical manifestations of skin cancer, raising patients awareness of the negative effects of ultraviolet radiation and solariums, the need for protection against ultraviolet irradiation, the use of methods of self-examination, timely reference to a doctor

Keywords: melanoma, carcinoma skin, Kaposi's sarcoma, morbidity, prevalence, recurrence, mortality 
Згідно даним Національного каниер-реєстру Украӥни рівень захворюваності на рак шкіри та показник смертності щзорічно збільшуються і перевищують світові показники. Тому проблема раку шкіри залишається актуальною, вимагає поліпшення рівня ранньої діагностики. Нами проаналізовано епідеміологічні особливості онкопатології шкіри серед прикріпленого контингенту Державної наукової установи «Науково-практичного центтру профілактичної та клінічної медицини» Державного управління справами

Ключові слова: меланома, карцинома шкіри, саркома Капоші, захворюваність, поширеність, рецедивування, смертність

\section{Introduction}

Dermatooncology as dermatology section deals with the study, diagnosis and treatment of benign and malignant tumours of the skin, based on the etiological and morphological features of a particular oncological entity of the skin lesions. As a rule, patients visit dermatologist or cosmetologist complaining of not a neoplasm on the skin, but due to the emergent cosmetic defect or subjective feelings. According to statistics, the incidence of malignant skin tumours among the patients who had an appointment with a dermatologist is $2 \%$ [1]. Patients with skin neoplasms make up about $13.2 \%$ in the structure of primary outpatient treatment [2].

The three most common types of skin cancer, in descending order, are basal cell carcinoma, squamous cell carcinoma, and melanoma. Basal cell carcinoma alone is thought to be more common than any other cancer, but central cancer registries* (CCRs) do not collect data on basal cell carcinoma, so incidence is unknown [3]. BCC is the most common of all cancers diagnosed in the United States with over 2000000.0 cases diagnosed annually. Squamous cell carcinoma is less common than basal cell carcinoma and can cause death, although most cases are treatable [4].

Melanoma is the least common of the three main types of skin cancer, but causes the most deaths. In 2012, CCRs in the United States reported approximately 67,000 new melanoma cases and 9,000 deaths from melanoma [5].

According to specified data of the National Cancer Registry of Ukraine in 2012-2013 a large share in the structure of morbidity of the Ukrainian population (from $10.4 \%$ in men to $13.4 \%$ in women) belonged to skin cancer of epithelial origin. The incidence rate of melanoma in men takes the $13^{\text {th }}$ place $(2.0 \%)$, while in women it takes the $11^{\text {th }}$ place (2.3\% among registered cancers) [6].

Skin cancer is caused not only by individual genetic factors, but also is strongly associated with ultraviolet (UV) radiation [7]. The causal relationship between UV exposure and skin cancer among populations with comparatively more sun-sensitive skin is well established, and recent genetic research has found a UV exposure signature among mutations specific to melanoma [8].

The rates of skin cancer have tripled since the early 1970s. Although much of the increase has been among early stage cancers, and mortality has remained relatively stable, more recent analyses have found increases among the later stage cancers, and mortality rates for males have begun to increase [9].

Developing methods to better measure the prevalence of basal cell carcinoma and squamous cell carcinoma could also provide important information to measure the impact of public health efforts [10].

\section{Case presentation}

The importance of the study of skin cancer is that the incidence of skin cancer in Ukraine is much lower than European rates. However, low awareness of the issue and the lack of centralized screening lead to late diagnosis and high mortality [11].

Despite significant achievements in cancer detection and "precancerous" diseases, the measures, which currently used, cannot be considered fully relevant to the requirements of population screening [12].

It should be noted that the most common type of the survey of people (sometimes of the very widespread contingent) with the greatest risk is the selective one. Furthermore, the survey group includes patients who go to medical institutions regarding noncancerous pathology. At the same time the survey identify malignant tumors, which often don't correspond preclinical stage because they have specific symptoms, even minimal [13].

Medical care for patients with skin cancer at State Institution of Science "Research and Practical Centre of Preventive and Clinical Medicine" of the State Administrative Department (SIS "RPC PCM" SAD) is provided more than 30 years, but the evaluation of the quality of this work is not carried out.

The study of epidemiological indices of oncological pathology of the skin among the contingent of SIS and their comparison with the corresponding indices among the population of Kiev and Ukraine will allow to determine the effectiveness of implemented treatment and diagnostic methods, of screening for skin cancer at the primary care level and identify ways to improve the provision of medical care for oncology patients of SIS.

\section{Materials and Methods}

The basis for the research of the epidemiological features of skin cancer among the contingent of SIS is personalized information on patients that's stored in the database of the SIS since 1996. For the retrospective epidemiological analysis were used data from 2005 to 2014. The article presents the results of statistical treatment morbidity, prevalence and mortality of patients with melanoma and non-melanoma skin cancers, which were under the supervision of a physician dermatologist of SIS. The obtained results were compared with corresponding figures among patients from Kyiv and Ukraine.

\section{Results}

Medical care for patients with oncological pathology of the skin at State Institution of Science "Research and Practical Centre of Preventive and Clinical Medicine" of the State Administrative Department (SIS 
"RPC PCM" SAD) is provided according to the approved Local protocol of medical care for patients with melanoma "The Unified Clinical Protocol of Primary, Secondary (Specialized), Tertiary (Highly Specialized) Medical Care "Melanoma", which was developed under the decree of the Ministry of Health of Ukraine No. 234 from 02/04/2014, and Local protocols of medical care for patients with squamous and basal cell skin cancer, Kaposi's sarcoma. Oncological pathology of the skin among the contingent of SIS "RPC PCM" SAD (hereinafter contingent of SIS) constitutes a significant part. As at 01/01/2014868 patients with skin cancer were subject to regular medical check-up, representing $31.8 \%$ from total number of oncology patients of SIS and $38.7 \%$ from total number of individuals who are subject to regular medical check-up of dermatologist at SIS. During 2014 there ha- ve been 78 patients with first diagnosed skin cancer who were subject to regular medical check-up (65\% from total number of patients with oncological pathology of the skin who were subject to regular medical check-up in 2014). Non-melanoma skin cancers made up $90.4 \%$ (785 cases), and melanoma patients made up only $9.3 \%$ (81 cases) (refer to Fig. 1).

In 2014 among the contingent of SIS there were registered 6 patients with the first diagnosed melanoma; morbidity rate was 16.0 per 100,000 people (a decrease by $14.0 \%$ compared with the corresponding figure in 2013) (refer to Fig. 2).

As at 01/01/2015 among the patients with melanoma there dominated men; they made up $51.9 \%$ (41 patients), and women $-48.1 \%$ (38 patients) respectively (refer to Fig. 3).

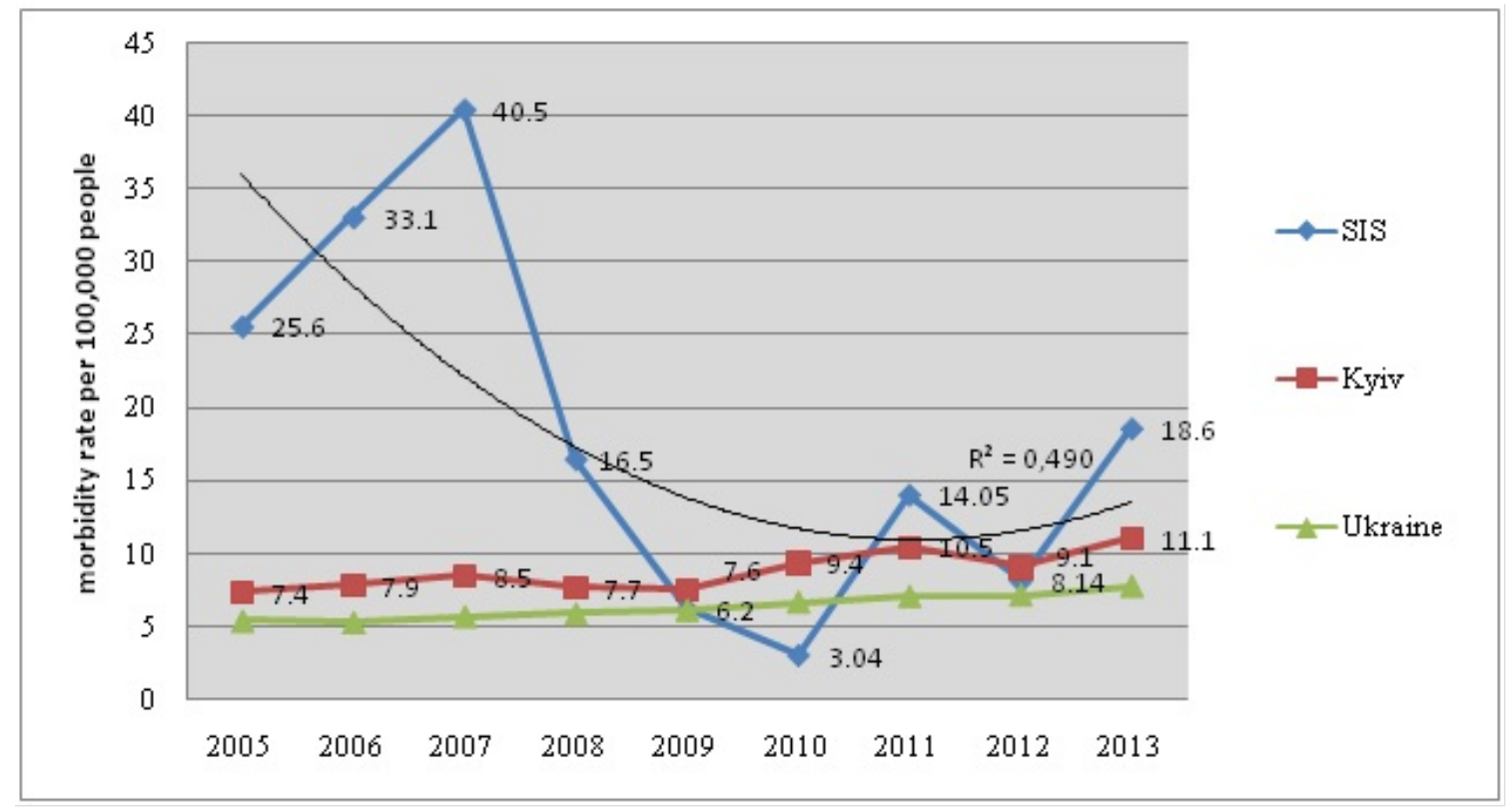

Fig. 1. Melanoma morbidity rate among the contingent of SIS, population of Kyiv and Ukraine in 2005-2013: * - polynomial trend line

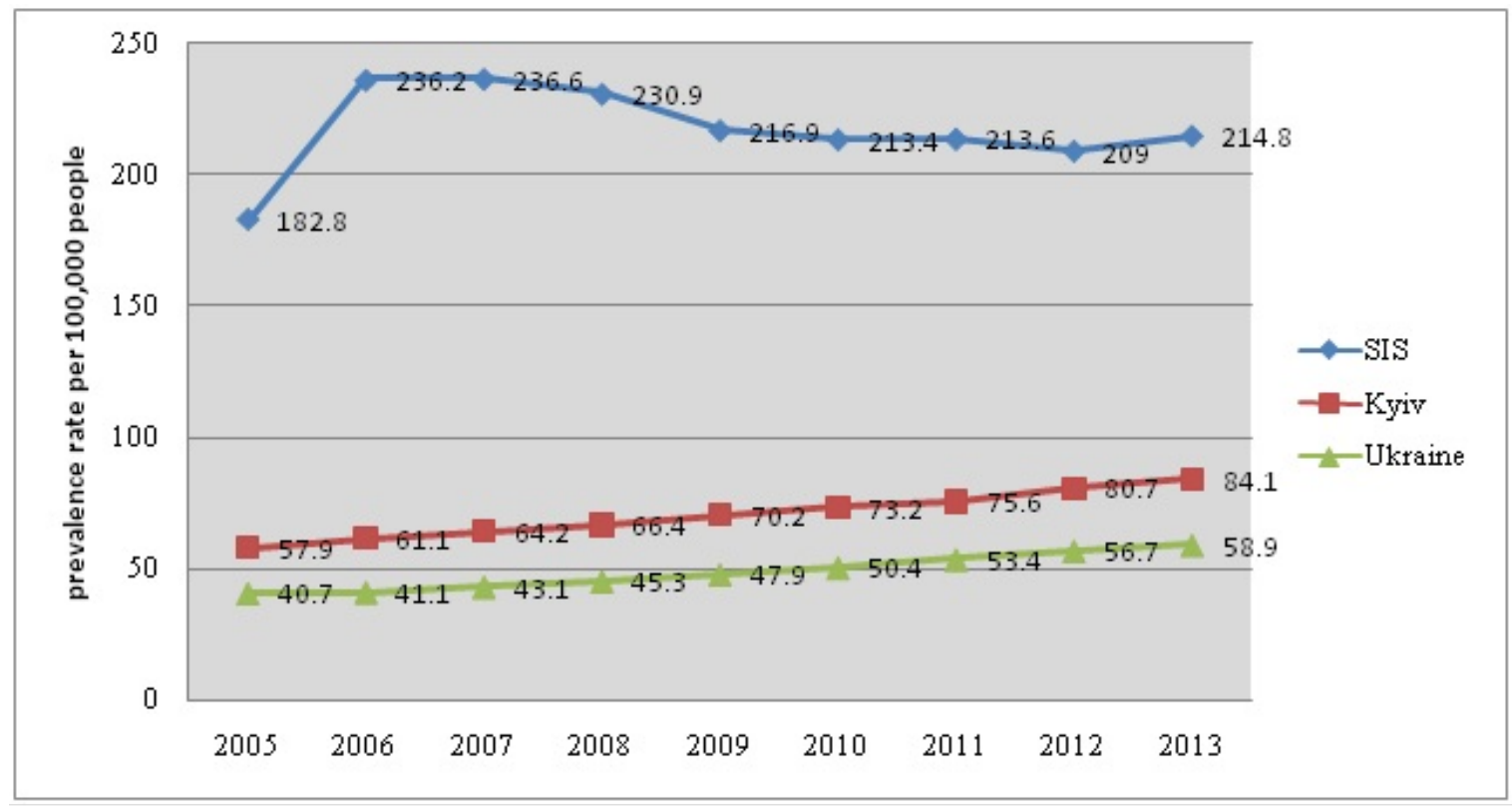

Fig. 2. Melanoma prevalence rate among the contingent of SIS, population of Kyiv and Ukraine in 2005-2013 
Among men with melanoma there dominated age groups of 75 years old and older $(48.8 \%)$ and $65-$ 74 years old (31.7\%); age groups of 55-64 years old (12.2\%), 45-54 years old (2.4\%), 35-44 years old (4.9\%) were represented by isolated cases (refer to Fig. 3). Among women there dominated patients of 75 years old and older (31.6\%), 65-74 years old (26.3\%), 5564 years old $(23.7 \%)$. In the age groups of $45-54$ years old (2.6\%), 35-44 years old (13.2\%) and 25-34 years old $(2.6 \%)$ there were registered isolated cases (refer to Fig. 3).

The prevalence rate of melanoma among the contingent of SIS in 2013 was 214.8 per 100,000 people. In 2014 the prevalence rate of melanoma among the contingent of SIS was 210.3 per 100,000 people (a decrease by $2.1 \%$ compared with the corresponding figure in 2013) (refer to Fig. 2).
In 2014 among the contingent of SIS there were registered 72 patients with the first diagnosed NMSC; morbidity rate was 191.7 per 100,000 people (an increase by $3.3 \%$ compared with the corresponding figure in 2013) (refer to Fig. 4).

NMSC includes squamous cell carcinoma of the skin (SCCS; according toICD-10 - C44.1), basal cell carcinoma of the skin (BCCS; according to ICD-10 - C44.2) and Kaposi's sarcoma (KC; according to ICD-10 - C46). As at $01 / 01 / 2015830$ patients with NMSC are subject to the regular medical check-up, representing $91.1 \%$ from the total number of patients with the skin cancer. The dynamics of morbidity rate of NMSC of the contingent of SIS demonstrates the significant prevalence of BCCS (refer to Fig. 5).

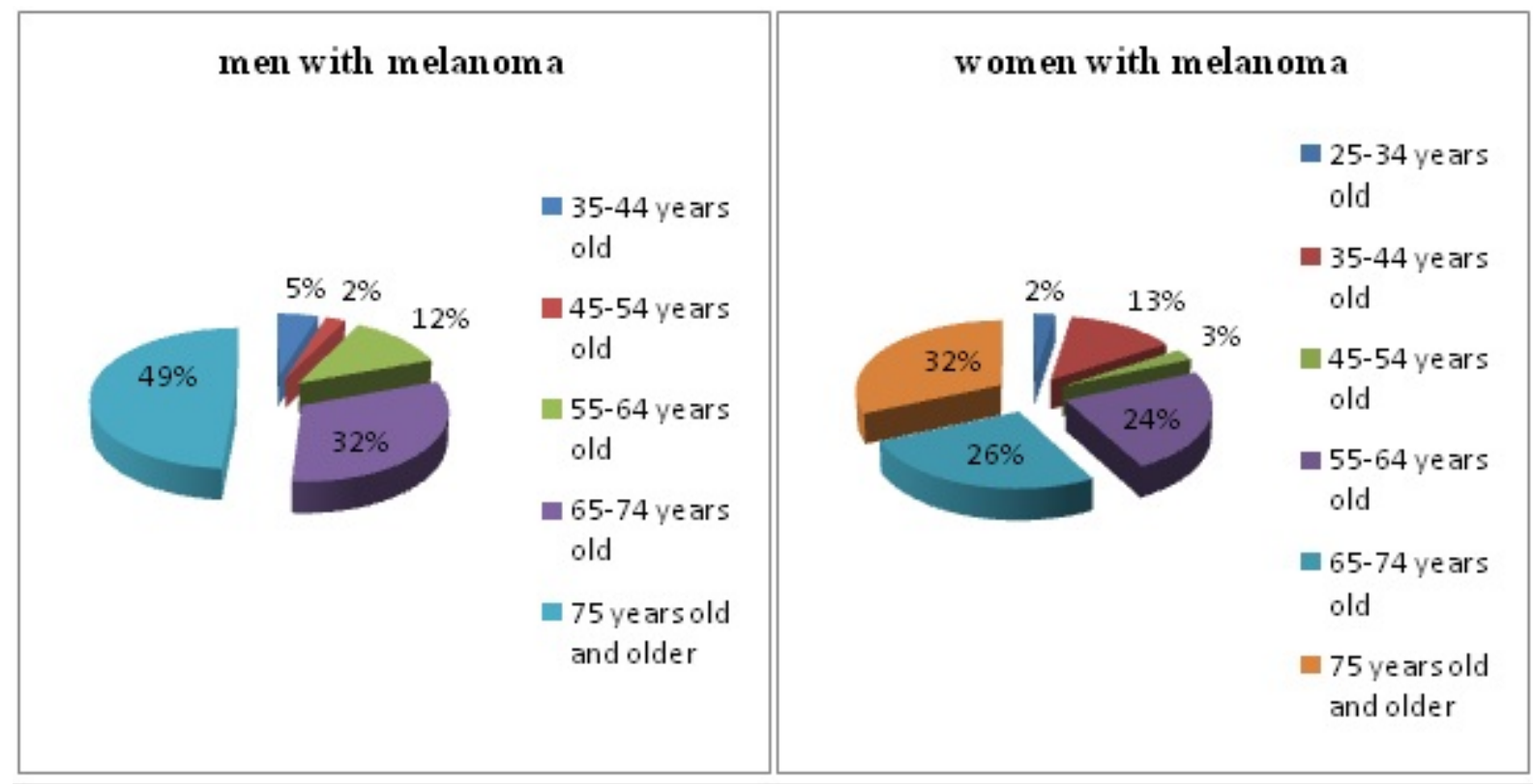

Fig. 3. Age distribution of patients with melanoma among the contingent of SIS as at 01/01/ 2015

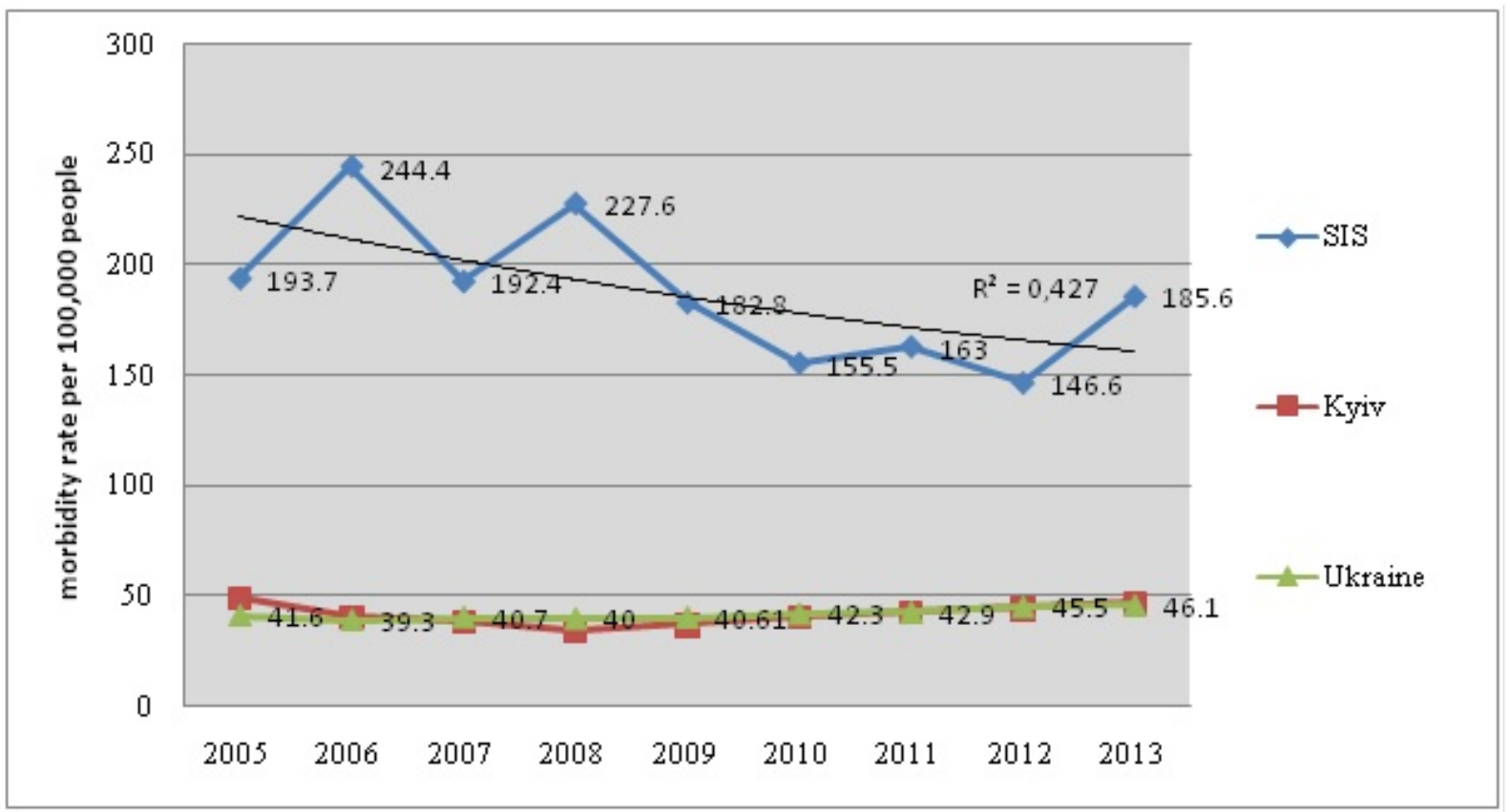

Fig. 4. NMSC morbidity rate of the contingent of SIS, population of Kyiv and Ukraine in 2005-2013: * - polynomial trend line 
Primary cases of $\mathrm{KC}$ were registered in 2007 (1case) and morbidity rate was 3.4 per100,000 people, in 2009 - 1 case (morbidityratewas 3.1 per 100,000 people) andin2014 - 1 case (2.7 per 100,000 people) (refer to Fig.5).

A sat 01/01/2014736 patients with BCCS were subject to the regular medical check-up $(84.8 \%$ from the total number of NMSC). In 2014106 patients with BCCS were taken under regular medical check-up, including 68 patients $(64.1 \%)$ with the first diagnosed skin cancer, and recurrent cases of BCCS made up $35.9 \%$ (refer to Fig. 5). As at 01/01/2015 780 patients with BCCS were subject to the regular medical check-up $(94.0 \%$ from total number of NMSC), among them men accounted for $61.9 \%$ (483 patients), women -38.1\% (297 patients).

Among men with BCCS there dominated patients of age group of 75 years old and older(73.6\%) and 6574 years old $(22.9 \%)$; in the age group of 55-64 years old $(3.6 \%)$ there were registered isolated cases (refer to Fig. 6). Among female patients there dominated persons of 75 years old and older $(63.9 \%)$ and $65-74$ years old
(26.7\%); there were registered isolated cases in the age groups of 55-64 years old (8.1\%) and 45-54 years old (1.2\%) (refer to Fig. 6).

As at 01/01/2014 47 patients with SCCS (6.0\% from the total number of NMSC) were subject to the regular medical check-up. In 2014 SCCS was diagnosed in 4 patients, including 3 patients $(75 \%)$ with first diagnosed SCCS (refer to Fig. 5). As to 01/01/2015 47 patients with SCCS (5.7 \% from the total number of NMSC) were subject to the regular medical check-up, including $57.4 \%$ of men (27 patients) and $42.6 \%$ of women (20 patients).

Among men with SCCS there dominated patients of age group of 75 years old and older $(44.4 \%)$ and $65-$ 74 years old $(48.1 \%)$; there were registered isolated cases in the age group of 55-64 years old (3.7\%) and 4554 years old (3.7\%) (refer to Fig. 7). Among female patients there dominated persons of 75 years old and older (70\%) and 65-74 years old (20\%); there were registered isolated cases in the age groups of 55-64 years old (5\%) and 35-44 years old (5\%) (refer to Fig. 7).

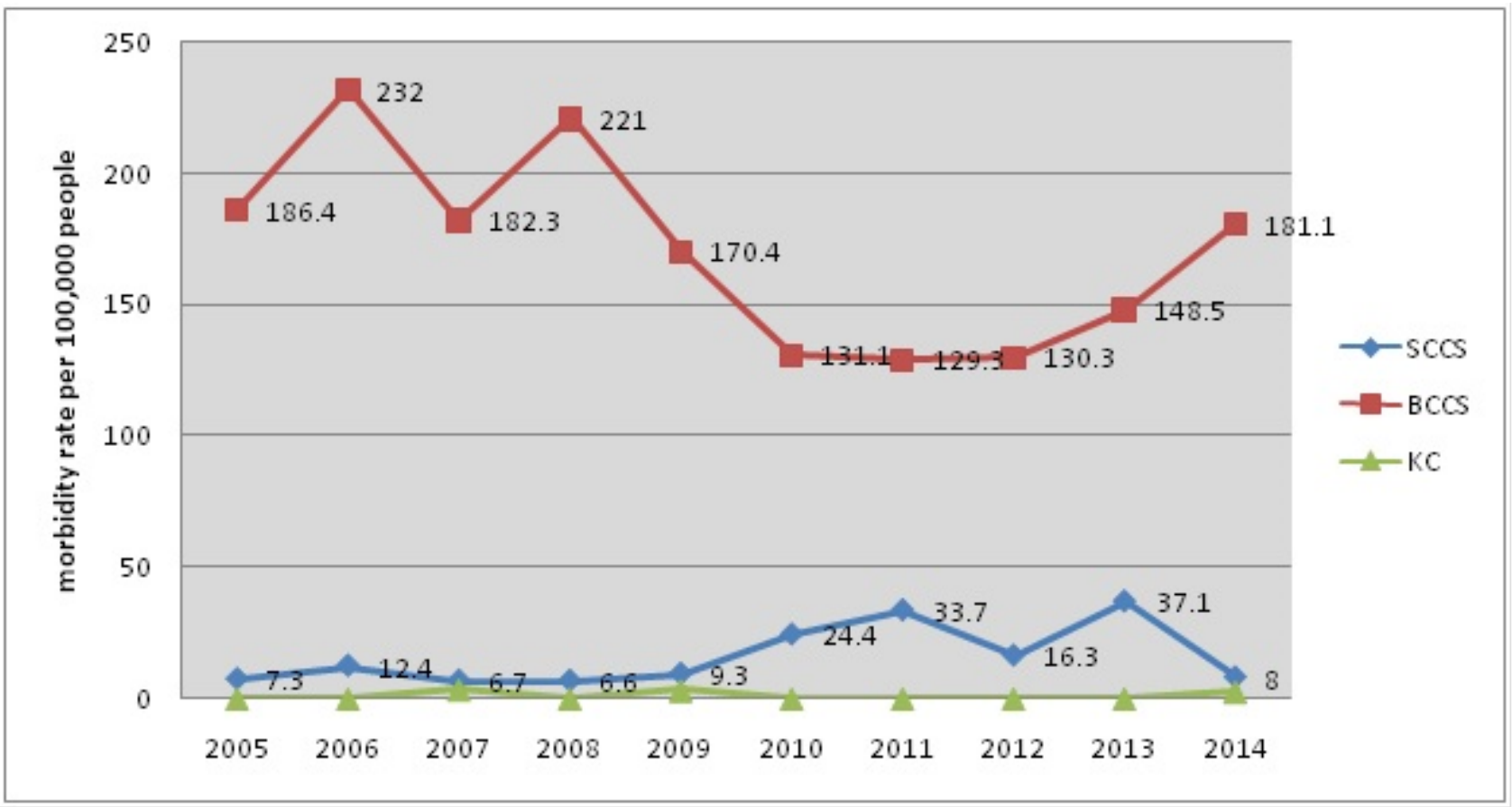

Fig. 5. Morbidity rate of SCCS, BCCS and KC of the contingent of SIS "RPC PCM" SAD in 2005-2014

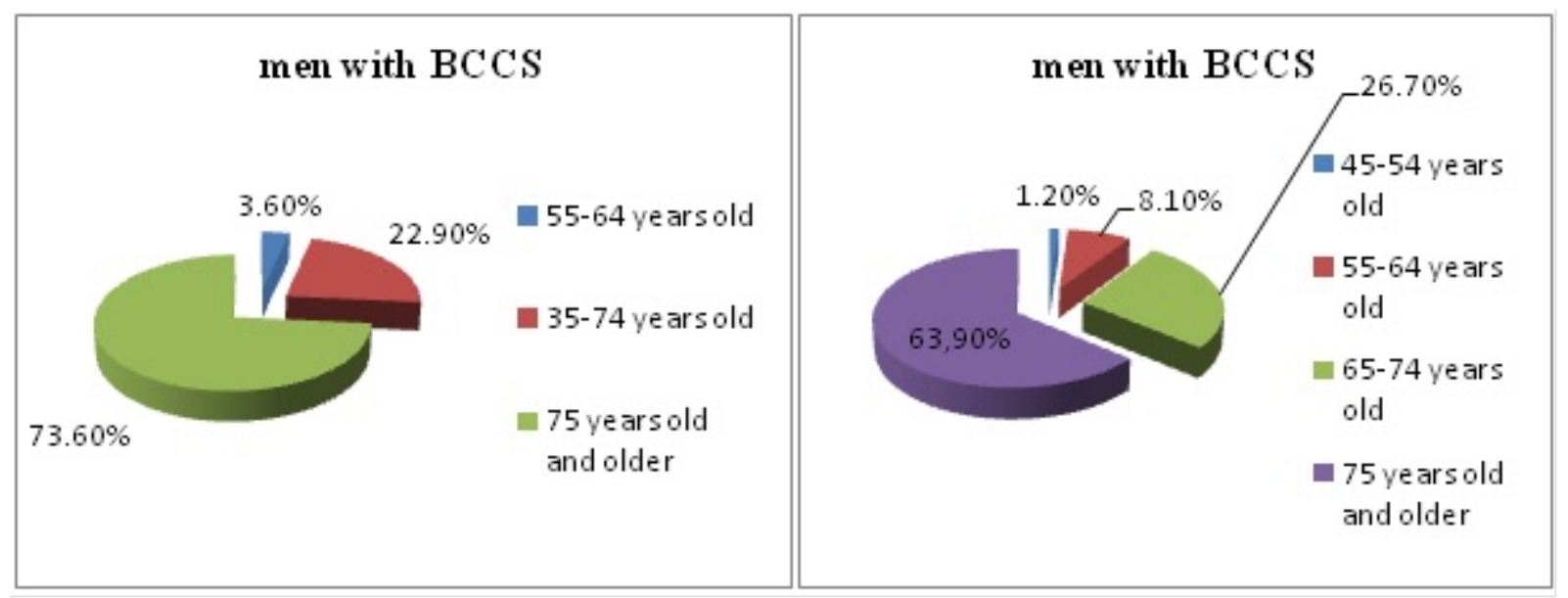

Fig. 6. Age distribution of patients with BCCS among the contingent of SIS as at 01/01/2015 
The prevalence rate of NMSC among the contingent of SIS in 2013 was 2081.3 per 100,000 people. In 2014 the prevalence rate of NMSC among the contingent of SIS was 2210.0 per 100,000 people (an increase by $6.2 \%$ compared to the corresponding figure in 2013) (refer to Fig. 8).

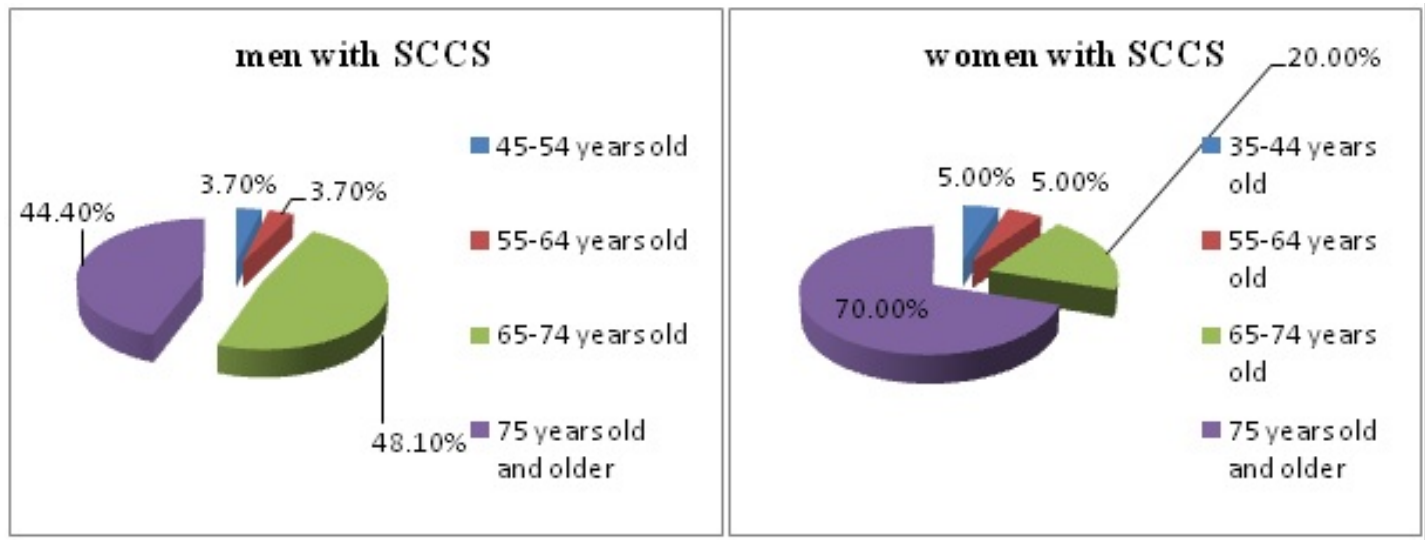

Fig. 7.Age distribution of patients with SCCS among the contingent of SIS as at 01/01/2015

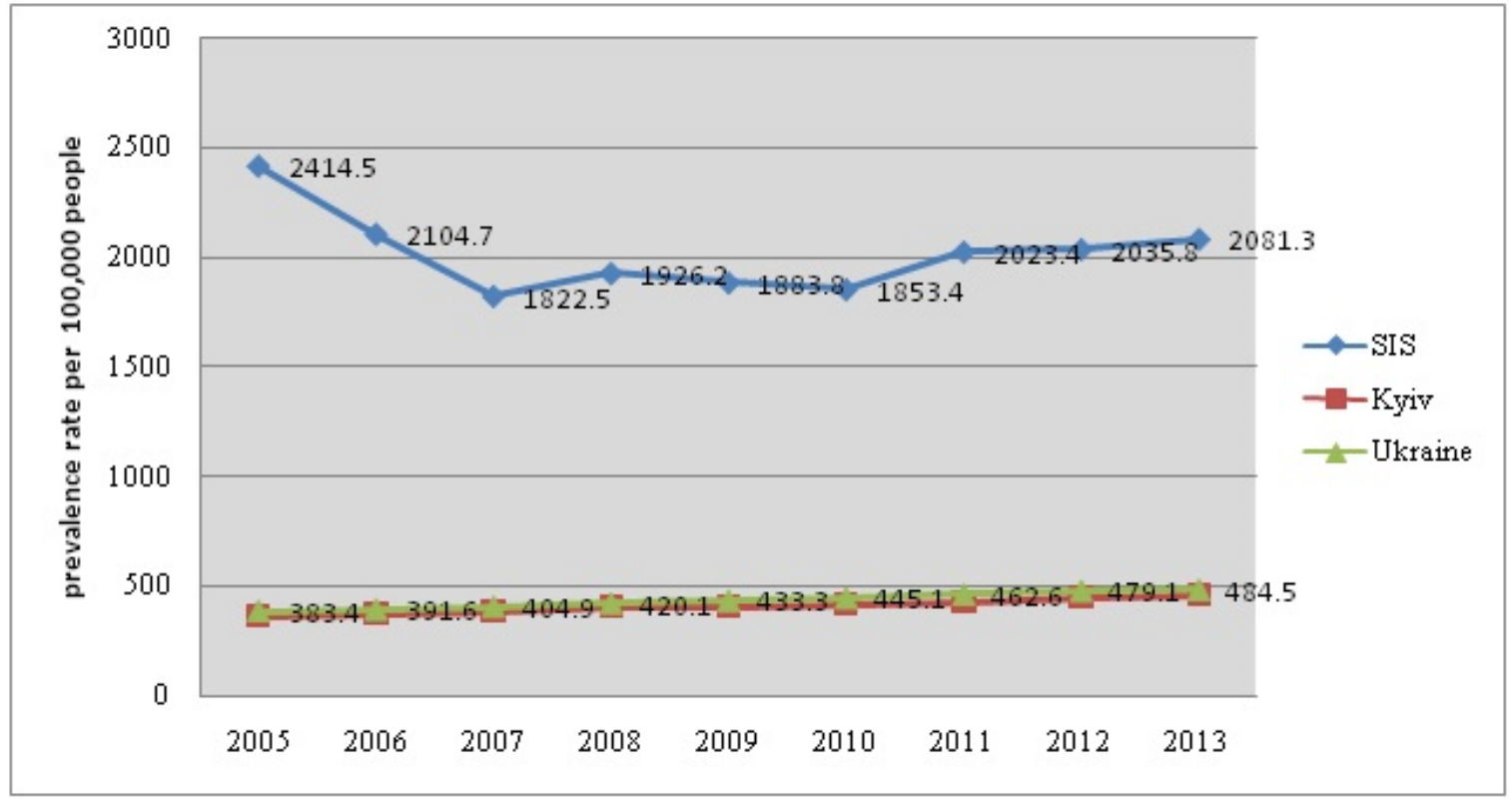

Fig. 8. Prevalence rate of NMSC among the contingent of SIS, population of Kyiv and Ukraine in 2005-2013

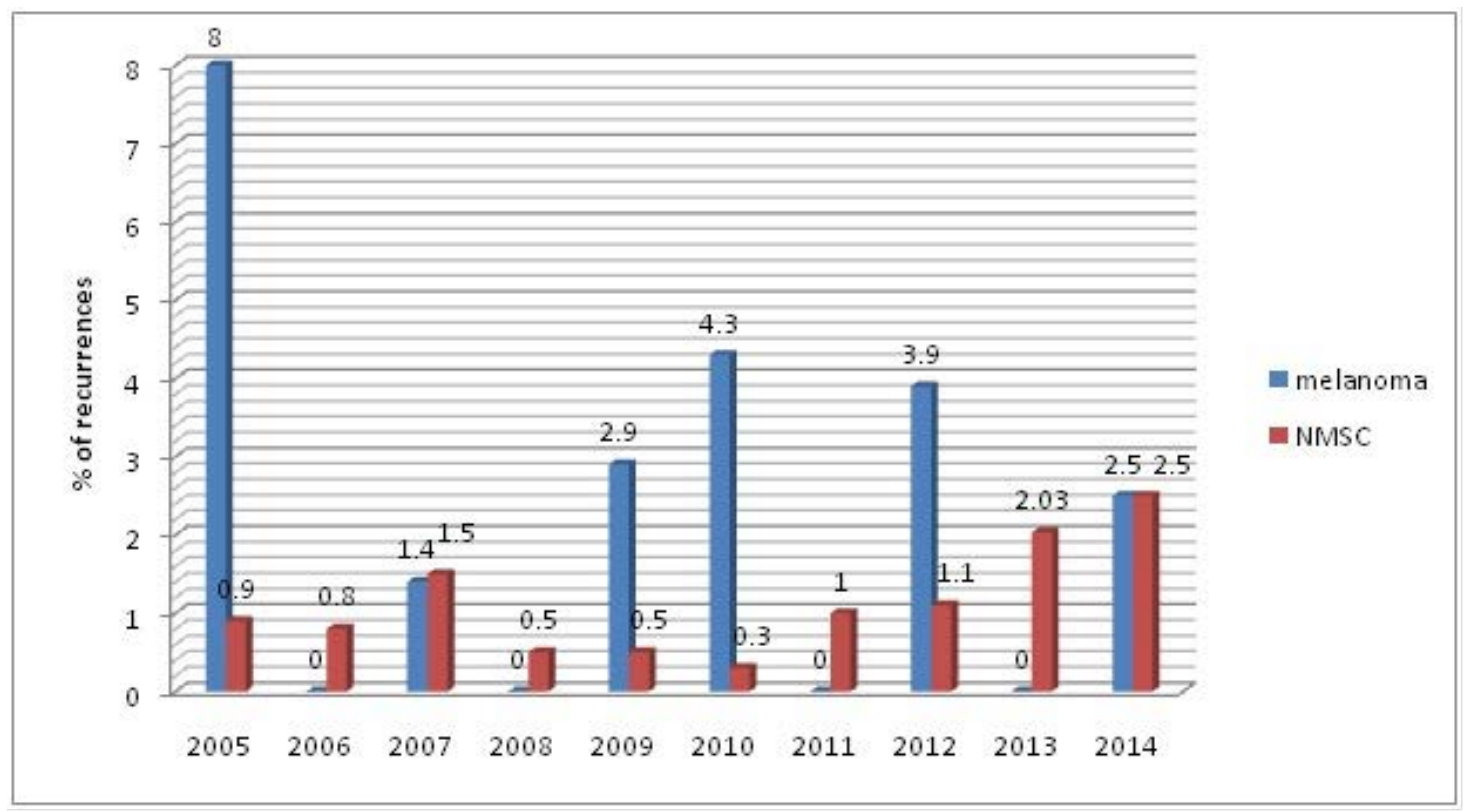

Fig. 9. Percentage of recurrences of melanoma and NMSC among the contingent of SIS in 2005-2014 
Among the contingent of SIS in 2005-2014 there was observed recurring oncological pathology of the skin. Thus, in patients with melanoma recurrence of the disease occurred on average in $2.3 \%$ of cases (from the total number of patients with the disease), and NMSC in $1.1 \%$ of cases (from the total number of patients with the disease) (refer to Fig. 9).

In 2013 the mortality rate among patients with melanoma of the contingent of SIS was 10.6 per 100,000 people. In 2014 the mortality rate among patients with melanoma of the contingent of SIS was 15.8 per 100,000 people (refer to Fig. 10).

In 2005 there was registered 1 death of patient with SCCS among the contingent of SIS and mortality rate was 3.7 per 100,000 people; in 2008 there was
1 death of patient with $\mathrm{KC}$ (mortality rate was 3.3 per 100,000 people) and in $2012-1$ death of patient with KC (mortality rate was 2.7 per 100,000 people). In 2014 deaths of patients with NMSC were not registered (refer to Fig. 11).

The majority of patients with melanoma have received combination therapy, which consisted of surgical excision of primary focus of the tumour followed by immunotherapy with interferon for 52 weeks. In the case of disease progression there were used chemical therapy and radiation therapy of metastatic foci (refer to Fig. 12).

Patients with Kaposi's sarcoma also mostly received combination therapy, which included partial surgical excision of tumour focus in combination with chemical therapy and radiation therapy (refer to Fig. 12).

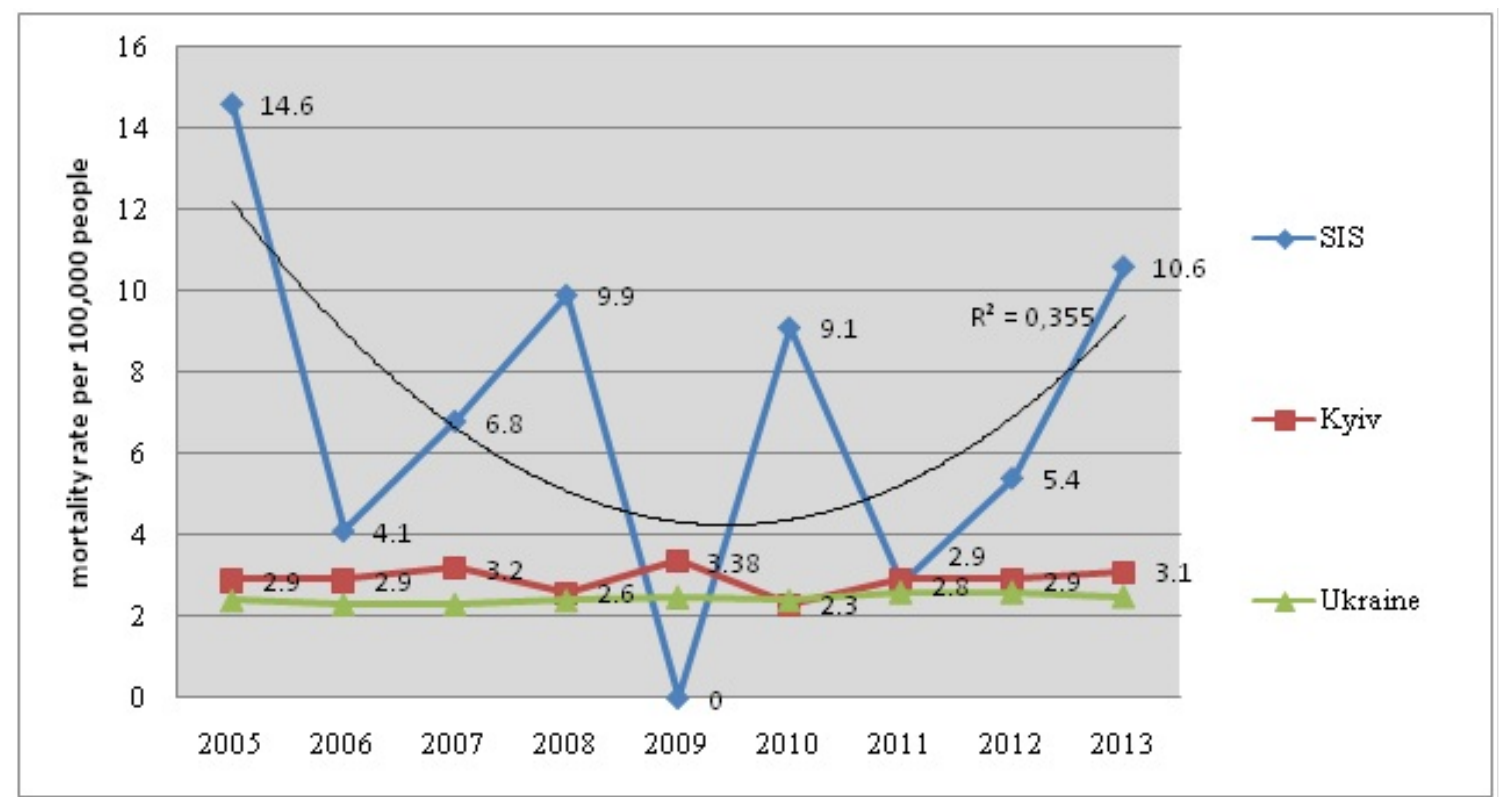

Fig. 10. Mortality rate of patients with melanoma among the contingent of SIS, population of Kyiv and Ukraine in 2005-2013: * - polynomial trend line

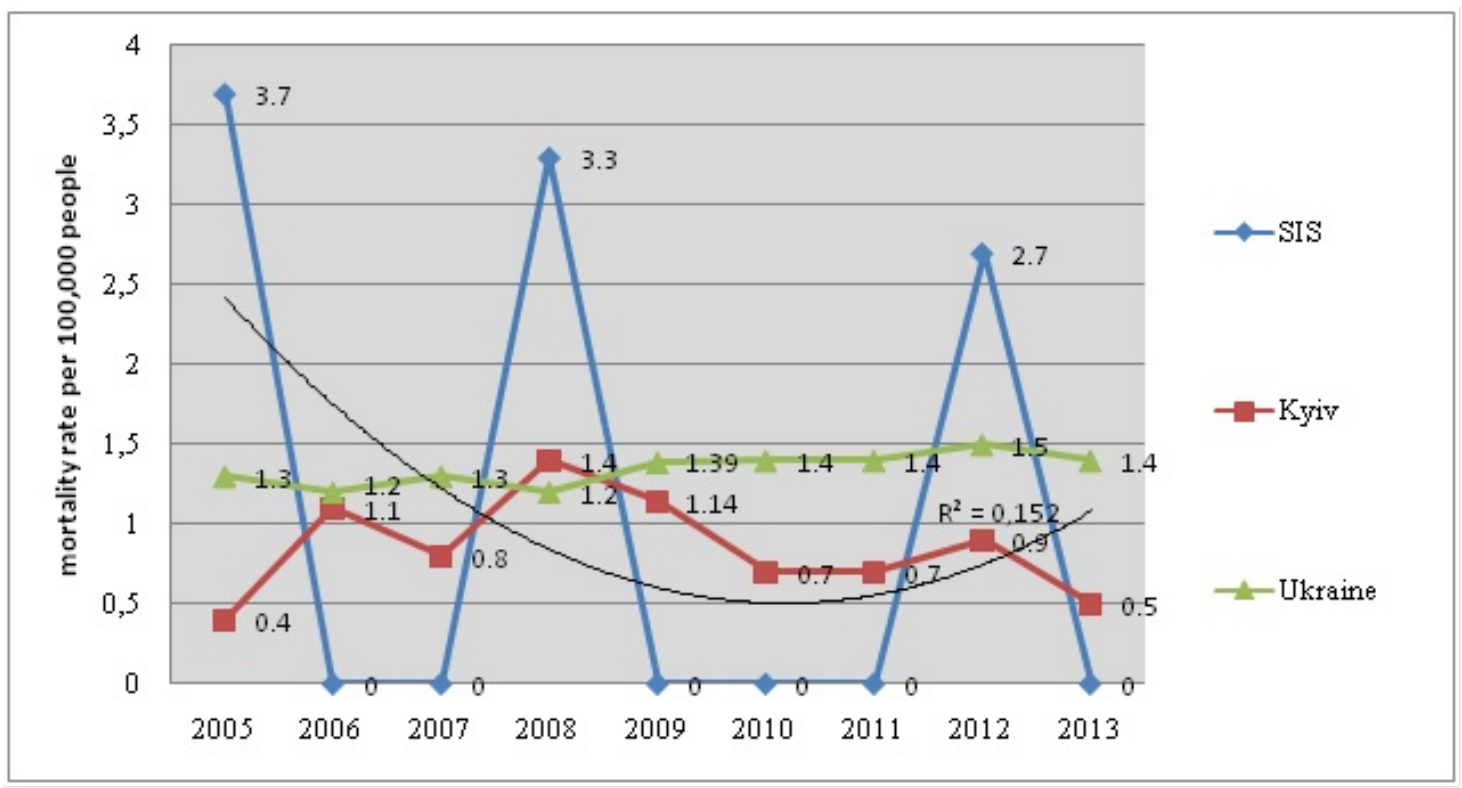

Fig. 11. Mortality rate of patients with NMSC among the contingent of SIS, population of Kyiv and Ukraine in 2005-2013: * - polynomial trend line 


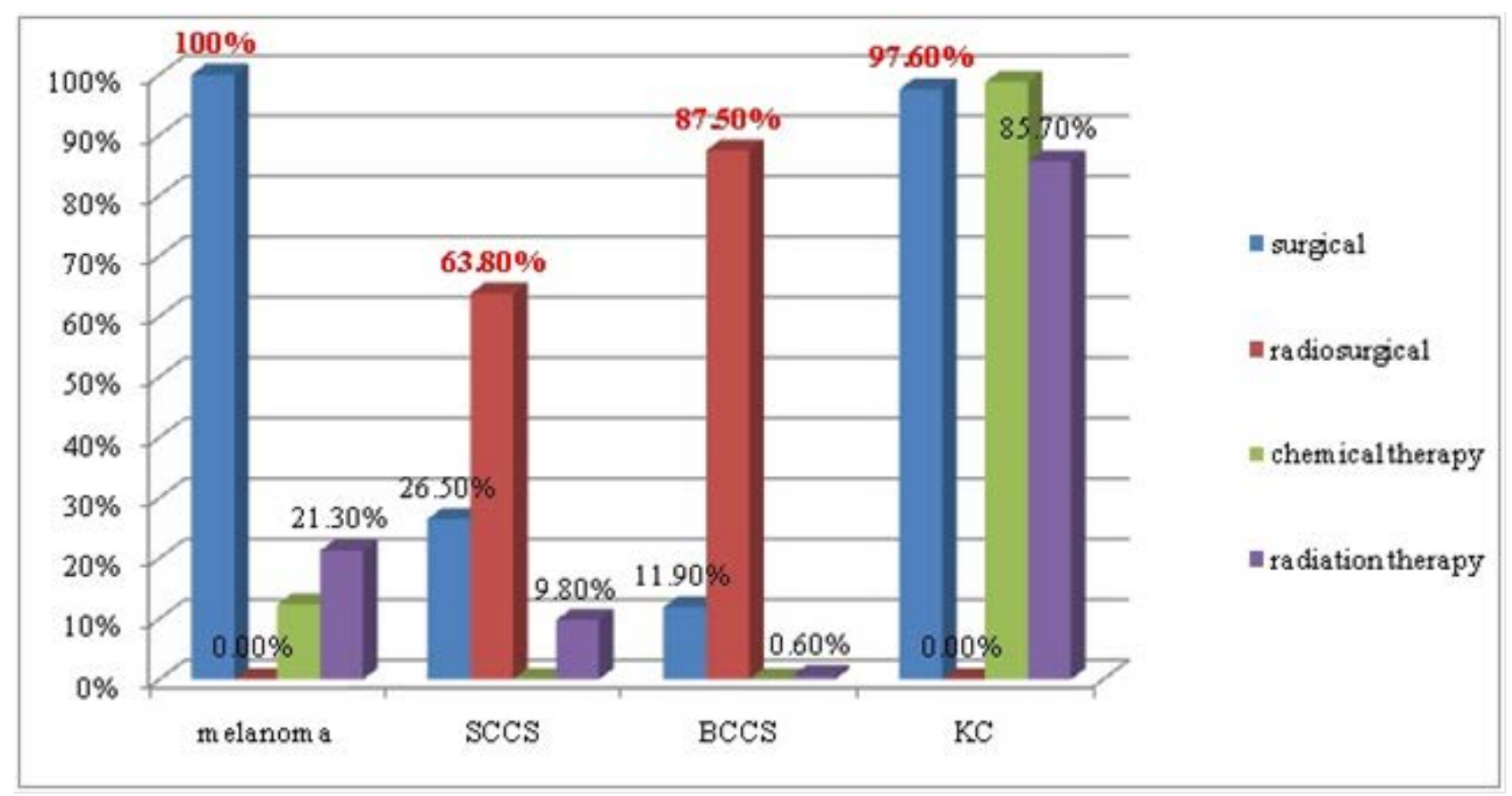

Fig. 12. Treatment of oncological pathology of the skin among the contingent of SIS in 2005-2014

SCCS and BCCS foci were mostly excised by radiosurgical method (63.8\% and $87.5 \%$ respectively), while in the case of large size tumours there was used surgical technique (26.5\% and $11.9 \%$ respectively) with additional radiation therapy in the case of deep tumour invasion (9.8\% and $0.6 \%$ respectively) (refer to Fig. 12).

Morphological verification index of the diagnosis of malignant skin diseases in 2014 was $100 \%$. The distribution of all identified new cases of skin cancer by stages (according to Ann Arbor classification and TNM) in 2014 showed that $83.3 \%$ of them were of the $1^{\text {st }}-2^{\text {nd }}$ stage of tumour growth, $14.1 \%-3^{\text {rd }}$ stage and $2.6 \%-4^{\text {th }}$ stage.

\section{Discussion}

Compared to the morbidity rate of melanoma among the population of Kyiv (11.1 per 100,000 people in 2013) and Ukraine (7.8 per 100,000 people in 2013) there is a significant prevalence in the morbidity rate among the contingent of SIS (18.6 per 100,000 people in 2013), despite the tendency to lower trend line $\mathrm{R}^{2}=0.490$ (refer to Fig. 1).

The prevalence rate of melanoma significantly predominates among the population of Kyiv (84.1 per 100,000 people in 2013) and Ukraine (58.9 per 100,000 people in 2013) (refer to Fig. 2).

Comparing the age ranges of men and women, it should be noted that women have the change in the number of cases during the $1^{\text {st }}$ period $(15.8 \%)$ and $2^{\text {nd }}$ period of middle age $(52.6 \%)$. While in men there dominated the number of patients of the $2^{\text {nd }}$ period of middle age (46.3\%) and elderly age (48.8\%) (refer to Fig. 3 ).

Comparing the incidence rate of NMSC among the contingent of SIS (185.6 per 100,000 people in 2013) with the corresponding figure among the population of Kyiv (47.5 per 100,000 people in 2013) and Ukraine (46.1 per 100,000 people in 2013), there should be noted a significant prevalence in the incidence rate among the contingent of SIS despite the tendency to trend line lowering $\mathrm{R}^{2}=0.4277$ (refer to Fig. 4).

The morbidity rate of BCCS in 2014 was 181.1 per 100,000 people (refer to Fig. 5). Comparing the age ranges there should be noted that in men as well as in women dominates the number of patients of the $2^{\text {nd }}$ period of middle age (men $-26.4 \%$, women $-36.1 \%$ ) and elderly age (men $-73.6 \%$, women $-63.9 \%$ ) (refer to Fig. 6).

The morbidity rate of SCCS in 2014 was 8.0 per 100,000 people, which is significantly lower than in 2013 37.1 per 100,000 people (refer to Fig. 5). Comparing the age ranges there should be noted that in men the number of patients of the $2^{\text {nd }}$ period of middle age $(55.6 \%)$ and elderly age (44.4\%) dominates and in women the number of patients of elderly age (70 \%) dominates (refer to Fig. 7).

The prevalence rate of NMSC was significantly higher than the corresponding figure among the population of Kyiv (460.0 per 100,000 people in 2013) and Ukraine (484.5 per 100,000 people in 2013) (refer to Fig. 8).

The mortality rate of patients with melanoma among the contingent of SIS in 2013 (10.6 per 100,000 people) was significantly higher than the corresponding figure among the population of Kyiv (3.1 per 100,000 people) and Ukraine (2.5 per 100,000 people) and trend line tends to increase $\mathrm{R}^{2}=0.3554$ (refer to Fig. 10).

But despite the absence of annual mortality of patients with NMSC the mortality rate among these patients of the contingent of SIS is higher than the corresponding figures among the population of Kyiv ( 0.9 per 1000,000 people) and Ukraine ( 1.5 per 1000,000 people) and trend line tends to slight increase $\mathrm{R}^{2}=0.1521$ (refer to Fig.11).

\section{Conclusions}

1. The relevance of the study of oncological pathology of the skin is due to the annual increase of morbidity 
rate of skin cancer and significantly high mortality rate among patients.

2. The study of epidemiological indices of oncological pathology of the skin among the contingent of SIS showed the following results:

- the morbidity rate of melanoma and NMCS is higher than the corresponding figures of the population of Kyiv and Ukraine, despite the decline in the incidence of melanoma in 2014 by $14 \%$ compared to the year 2013 ;

- the mortality rate of patients with skin cancer, mainly due to patients with melanoma, among the contingent of SIS is also higher than the corresponding figures of the population of Kyiv and Ukraine;

- the majority of patients with skin cancer were men of the $2^{\text {nd }}$ period of middle age and elderly age;

- the highest morbidity rate of skin cancer was registered in the age groups of 65-74 years old and 75 years old and old regardless of gender;

- identifying early stages of tumour in patients were $83.3 \%$;

- recurrence and prolongation of oncological process were registered among patients with melanoma in $2.3 \%$, and among patients with NMCS $-1.1 \%$ annually.

3. The above statistics show the need for effective prevention of skin cancer among the contingent of SIS:

- raising patients awareness of negative effect of excessive ultraviolet radiation and solariums, the need for protection against ultraviolet irradiation, the use of methods of self-examination, timely reference to the doctor;

- raising awareness of primary care physicians of early clinical manifestations of visual cancer types, the selection of individuals with risk factors for the skin cancer development and observation of such persons, timely examination of patients with suspected skin cancer by dermatologist, oncologist;

- advanced training of dermatologists, oncologists, surgeons and other specialists as to the methods of diagnosis, treatment and observation of patients with skin cancer;

- detection of oncological pathology of the skin and taking diagnostic and therapeutic measures in this group of patients to prevent malignant transformation.

\section{References}

1. Thomas, J. G. Screening for cancer: evaluating the evidence [Text] / J. G. Thomas // Am. Fam. Physician. - 2001. Vol. 63, Issue 3. - P. 513-523.

2. Lamotkin, I. A. Tumors and tumor-like lesions of the skin. Atlas [Text] / I. A. Lamotkin. - M.: Binom. Laboratory Knowledge, 2006. - 166 p.

3. The Surgeon General's call to action to prevent skin cancer. US Department of Health and Human Services [Text]. Washington DC: US Department of Health and Human Services, 2014. - 112 p. - Available at: http://www.surgeongeneral.gov/ library/calls/prevent-skin-cancer/call-to-action-prevent-skincancer.pdf

4. Cancer of the Skin [Text] / D. S. Rigel, J. K. Robinson, M. I. Ross, R. Friedman (Eds.). - 2-nd ed. - Saunders, 2011. - 720 p.

5. US Cancer Statistics Working Group. United States cancer statistics: 1999-2012 incidence and mortality web-based report [Text]. - Atlanta, GA: US Department of Health and Human Services, CDC and National Institutes of Health, National Cancer Institute, 2015. - Available at: https://nccd.cdc.gov/uscs 6. Fedorenko, Z. P. Rak v Ukrai'ni 2012-2013 [Text] / Z. P. Fedorenko, L. O. Gulak, Yu. Y. Mikhailovich et. al // Bulletin of National Cancer Registry of Ukraine № 15. - Kyiv, 2014. - Available at: http://www.ncru.inf.ua/publications/BULL_15/index.htm

7. Leiter, U. Epidemiology of melanoma and non-melanoma skin cancer - the role of sunlight $[$ Text $]$ / U. Leiter, C. Garbe // Advances in Experimental Medicine and Biology. 2008. - Vol. 624. - P. 89-103. doi: 10.1007/978-0-387-77574-6_8

8. Genomic Classification of Cutaneous Melanoma [Text] // Cell. - 2015. - Vol. 161, Issue 7. - P. 1681-1696. doi: 10.1016/j.cell.2015.05.044

9. Jemal, A. Recent trends in cutaneous melanoma incidence and death rates in the United States, 1992-2006 [Text] / A. Jemal, M. Saraiya, P. Patel, S. S. Cherala, J. Barnholtz-Sloan, J. Kim et. al // Journal of the American Academy of Dermatology. - 2011. - Vol. 65, Issue 5. - P. S17.e1-S17.e11. doi: 10.1016/ j.jaad.2011.04.032

10. Watson, M. CDC Grand Rounds: Prevention and Control of Skin Cancer [Text] / M. Watson, C. C. Thomas, G. M. Massetti, S. McKenna, J. E. Gershenwald, S. Laird // MMWR. Morbidity and Mortality Weekly Report. - 2015. - Vol. 64, Issue 47. P. 1312-1314. doi: 10.15585/mmwr.mm6447a2

11. Kotenko, K. Malignant tumors of the skin in Ukraine [Text] / K. Kotenko // Zdorov'ia Ukrainy. - 2011. - Issue 3. - P. 28-29.

12. Vorobiov, A. General screening questions [Text] / A. Vorobiov, A. Protasova // Practical Oncology. - 2010. - Vol. 11, Issue 2. - P. 53-59.

13. Aitken, J. F. Increase in skin cancer screening during a community-based randomized intervention trial [Text] / J. F. Aitken, P. H. Youl, M. Janda, J. B Lowe, I. T. Ring, M. Elwood // International Journal of Cancer. - 2005. - Vol. 118, Issue 4. P. 1010-1016. doi: 10.1002/ijc.21455

\section{References}

1. Thomas, J. G. (2001). Screening for cancer: evaluating the evidence. Am. Fam. Physician., 63 (3), 513-523.

2. Lamotkin, I. A. (2006). Tumors and tumor-like lesions of the skin. Atlas. Moscow: Binom. Laboratory Knowledge, 166.

3. The Surgeon General's call to action to prevent skin cancer. US Department of Health and Human Services (2014). Washington DC: US Department of Health and Human Services, 112. Available at: http://www.surgeongeneral.gov/library/calls/ prevent-skin-cancer/call-to-action-prevent-skin-cancer.pdf

4. Rigel, D. S., Robinson, J. K., Ross, M. I., Friedman, R. (Eds.) (2011). Cancer of the Skin. Saunders, 720.

5. US Cancer Statistics Working Group. United States cancer statistics: 1999-2012 incidence and mortality web-based report (2015). Atlanta, GA: US Department of Health and Human Services, CDC and National Institutes of Health, National Cancer Institute. Available at: https://nccd.cdc.gov/uscs

6. Fedorenko, Z. P., Gulak, L. O., Mikhailovich, Yu. Y. et. al. (2014). Rak v Ukrai'ni 2012-2013. Bulletin of National Cancer Registry of Ukraine № 15. Kyiv. Available at: http://www.ncru. inf.ua/publications/BULL_15/index.htm

7. Leiter, U., Garbe, C. (2008). Epidemiology of melanoma and non-melanoma skin cancer - the role of sunlight. 
Advances in Experimental Medicine and Biology, 624, 89-103. doi: 10.1007/978-0-387-77574-6_8

8. Genomic Classification of Cutaneous Melanoma (2015). Cell, 161 (7), 1681-1696. doi: 10.1016/j.cell.2015.05.044

9. Jemal, A., Saraiya, M., Patel, P., Cherala, S. S., Barnholtz-Sloan, J., Kim, J. et. al (2011). Recent trends in cutaneous melanoma incidence and death rates in the United States, 1992 2006. Journal of the American Academy of Dermatology, 65 (5), S17.e1-S17.e11. doi: 10.1016/j.jaad.2011.04.032

10. Watson, M., Thomas, C. C., Massetti, G. M., McKenna, S., Gershenwald, J. E., Laird, S. (2015). CDC Grand Rounds:
Prevention and Control of Skin Cancer. MMWR. Morbidity and Mortality Weekly Report, 64 (47), 1312-1314. doi: 10.15585/ mmwr.mm6447a2

11. Kotenko, K. (2011). Malignant tumors of the skin in Ukraine. Zdorov'ia Ukrainy, 3, 28-29.

12. Vorobiov, A., Protasova, A. (2010). General screening questions. Practical Oncology, 11 (2), 53-59.

13. Aitken, J. F., Youl, P. H., Janda, M., Lowe, J. B, Ring, I. T., Elwood, M. (2005). Increase in skin cancer screening during a community-based randomized intervention trial. International Journal of Cancer, 118 (4), 1010-1016. doi: 10.1002/ijc.21455

Рекомендовано до публікачії д-р мед. наук, професор Коломоєиь М. Ю.

Дата надходження рукопису 25.02.2016

Oshyvalova Olena, $\mathrm{PhD}$, Senior Research Fellow, Scientific Department of medical care, State Scientific Institution "Scientific and Practical Centre of Preventive and Clinical Medicine" the State Administration, Verchnya str., 5, Kyiv, Ukraine, 01014

E-mail: ochivalova@mail.ru

UDC 616.72-002-021.5-053.2-07:612.017

DOI: $10.15587 / 2313-8416.2016 .64834$

\title{
THE STATE OF IMMUNOLOGICAL REACTIVITY AND NONSPECIFIC PROTECTION FACTOR (LYSOZYME) IN CHILDREN WITH REACTIVE ARTHRITIS
}

\section{(C) V. Savvo, T. Tverdohleb}

\begin{abstract}
Aim. An improvement of diagnostics and prognostication of ReA clinical course in children on the base of studying the immunological reactivity and non-specific protection factor (lysozyme).

Materials and methods. Examination of children took place in the municipal children's cardiorheumatologic department of MHPI “Kharkov municipal children's clinical hospital № 24” and municipal children's polyclinic of the Kharkov city (№ 1, 2, 7, 12, 13, 14, 23).

40 children with ReA underwent immunological examinations, detection of sIgA in the saliva and lysozyme in the blood serum in acute period and in 9-12 months after the beginning of disease. 19 children (47,5\%) - 2-6 years old, 21 children (52,5\%) - 7-14 years old. Boys - $22(55,0 \%)$, girls - 18 (45,0\%). The mean age of children in group was

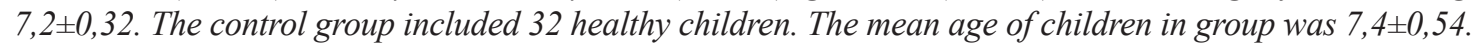

The ReA diagnosis was set according to the order of Ukrainian MHP of 19.07.2005 № 362 "Protocol of diagnostics and treatment of disease of musculoskeletal system and connective tissue in children ICD-D M00-M25 arthropathies". Immunological examinations included the study of indices of cellular, humoral, monocytic-phagocytic links of immunity, content of cytokines (IL-1,$I L-6)$, detection of SIgA and index of nonspecific protection factor (lysozyme). Assessment of results of researches was carried out using STATISTICA program for Windows (version 10.0), Microsoft Excel 2012, MATLAB 2015 a.
\end{abstract}

Results. In the ReA acute period in children was observed depression of T-system on the background of activation of immunity B-system as the reliable decrease of CD8, CD25 and increase of CD21. There was revealed an increase of IL-6, increase of phagocytic number, spontaneous NBT-test and spontaneous neutrophils activity index. The sIgA level reliably exceeded the standard. At determination of lysozyme the blood serum of patients with ReA in acute period was revealed its deficiency comparing with the standard.

In 9-12 months after the beginning of disease in subgroup of children with prolonged and relapsing clinical course was preserved the increase of IL-6 level and decrease of CD8, CD25 and increase of CD21, increase of sIgA and low content of lysozyme. The indicators of the favorable ReA outcome (remission) are: normalization of indices of T- and B-cellular link of immunity, IL-6, sIgA and lysozyme.

\section{Conclusions.}

1. In the ReA acute period was detected the decrease of CD8, CD25, increase of CD21and IL-6. The phagocytic link of immunity functions in the hypercompensation mode with emaciation (decompensation) phenomena. The sIgA content is increased and lysozyme level is decreased.

2. In 9-12 months after the beginning of disease in subgroup of children with remission was detected normalization of indices of T- and B-cellular links of immunity IL-6, sIgA and lysozyme. In subgroup of children with prolonged and relapsing clinical course was preserved increase of CD21, IL-6, sIgA and decrease of CD8, CD25 and lysozyme Keywords: reactive arthritis, children, cellular and humoral immunity, cytokines, secretory immunoglobulin A, lysozyme 